ISSN0975-3311

UJBM, Vol. 8, No. 2, July - December 2009, pp 1-8

https://doi.org/10.12725/ujbm.15.1

\title{
ASSORTED FACETS OF ETHICS FOR SUCCESSFUL BUSINESS
}

\author{
Anitha H.S.* \& Kavitha S.**
}

\section{ABSTRACT}

Ethics is a pedestal for any business to get good name and fame to endure for a long period in the competitive market. Code of ethics differs from one business to another, depending upon nature of the business. But for every business it is crucial and indispensable to follow ethical measures in its day to day business to enhance corporate ethical values to uplift or to promote ethical standards in an organization by bringing professional ethics and responsibilities among human resource of the company. Nowadays all the companies have made it mandatory to educate about ethics. Beyond that, they have started to practice it. As soon as an employee gets inducted to the company, a copy of the code of conduct will be given to him to understand the ethical values of the company and to follow it up.

\section{Introduction}

Anybody can do the business, but doing ethically is very important for the success of it. Success of any business depends on many factors, mainly

* Dept of Commerce, Kuvempu University PG Centre, Davangere.

** Academic Co-ordinator, INC, Davangere. 
internal and external management of the company. Internal management refers to managing within the organization like, managing various functions in and around the business (Finance, Marketing, Human Resource, and Production etc.). External management denotes (Legal, Domestic Market and International Environment, coping up with recession and uncertainties in the market). Executing these things ethically is very important, since all these factors play a significant role in the business and ethical values grow as most important factors of corporate success. Key intention of this literature is to enhance the border of the debate on corporate success in an era of societal globalization and boost an understating of its influence further than the fiscal space.

In this stiff domestic and international competitive era, ethical practices at business are becoming significant matter since corporate keep relationships with various people like their customers, suppliers, creditors, debtors, investors so on. The relationships are based on ethical practices and mutual trust. Taking business decisions ethically and be competent enough to face the world is the order of the business in the modern corporate globe. This article throws light upon importance of general and professional ethical practices. General ethical practices deal with maintaining corporate social responsibilities through corporate self-regulation bounded with ethical business model to protect the interest of the stakeholders, and general public. The issues which are related to honorable rights and duties among corporate, shareholders and with other companies also are thereby resolved.

\section{Different Facets of Ethics in Business}

Professional Ethics and Corporate Values go hand in hand. A few vital issues are discussed below:

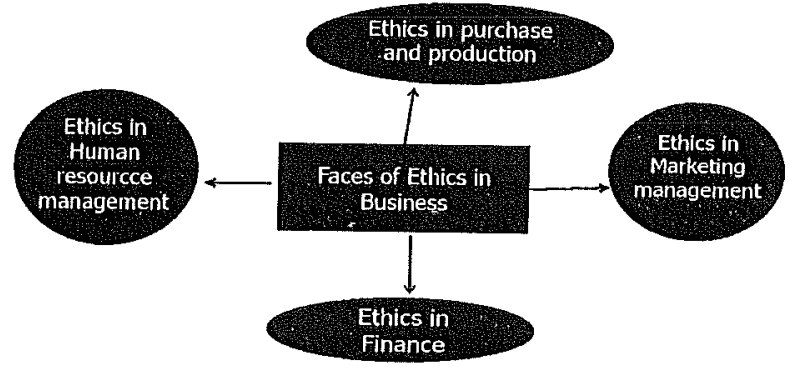

Source: Compiled by the Authors 


\section{Ethics in Finance}

Financial ethical norms are indispensable to maintain constancy and synchronization in financial aspects. Ethical violations in finance may lead to contradiction in the day to day activities of an organization. Since it is the life blood for any business and maintaining accounts in a proper manner is so important to avoid accounting frauds. And maintaining accounts and auditing them properly are the integral part of any business. Finance department is focal department in an organization to keep records of the business to smoothen functioning of day-to-day activities to shun interruptions and to have a close supervision. Because of this reason, monitoring will be facilitated in all kinds of organizations irrespective of the size of business to enrich value of the company by increasing company's profitability and to maximize shareholders value. Shareholders are depending upon audit report of the company since they cannot have an access to internal activities. Decision of investment in a company is based on report which is given by external auditor, when that it is manipulated intentionally or otherwise, and if that manipulation is disclosed to public, serious consequences will have to be faced by the companies. Moreover, it will affect the goodwill of the company in the long run. Best examples for accounting scams are Enron Corporation, World Communication in US. Much against to the expectations of the stakeholders, the recent example of Satyam Scam exposed itself to the accounting irregularities. Over Rs. 7,000 crores is being manipulated and still the investigation is on. Because of this scandal, share price of Satyam touched least price in the stock market and nearly 12,000 employees lost their jobs.' If this kind of unethical practice happens in the corporate field the consequences will be very awful. Insider trading like misusing the information of the company for their own gain, which is not available for common public, securities scams, over payment of executive compensation, bribing to get things done, unethical transactions, misusing public fund for personal benefit etc., are the common unethical practices in finance.

\section{Ethics in Human Resource Management:}

Human resource is one of the most important resources for any organization for smooth functioning of the business activities. Good and healthy relationship between the employer and employees is very important for long term survival and to strengthen organization by appropriate rights and responsibilities of the employer and employees. Usually conflicting issues 
can arise between employer and the employees due to many reasons viz., discriminations based on gender, race, religion etc., during recruitment, selection, promotion, poor occupational safety and health, sexual harassment, union strikes, privacy of the employers, unprotected employment laws etc. If was quite a big issue when FedEx Corporation involved in a controversy over racial discrimination and the whole system of the organization got disturbed. Hence, managing human resources is one of the challenging jobs in the modern business world.

\section{Ethics in Marketing}

Organizations' responsibilities are growing to meet the ethical values. Mere providing goods and services to the customers as is demanded by them are not sufficient. Marketing organizations are gearing up to provide quality goods at reasonable prices that too which are eco-friendly and which are not health hazardous. Early marketing literature shows the quantum of efforts put forth by the academics and practitioners in bringing a formal science of marketing with the help of strong ethos built for centuries to come.

Many MNCs owe their success for Market Orientation. They have found tremendous success by following marketing ethics. Marketers speak of customer relationship these days. They believe in long lasting relationships and their mantra is 'once a customer, always a customer'. Loosing a customer unnecessarily in the market is as good as committing a crime. Hence no marketer wants to commit a crime. Rather they are thinking of making customers delighted. Unethical marketing may put company into trouble so, practicing a moral principle is very important.

The thrust areas where a marketer's attention is drawn are manifold:

1. The 4 P's of marketing viz., Producing a good quality product; Pricing it reasonably; Placing it properly (Logistics) and Promoting it (providing a promotional cushion).

2. Choosing a suitable target market.

3. Developing want satisfying goods and services.

4. Channelizing the goods and services from the point of production to the point of consumption. 
5. Disseminating the required information in an ethical way without misleading the customers.

6. Avoiding unhealthy competition among competitors, like getting secrets of companies through unethical ways and means. ${ }^{2}$

\section{Ethics in Purchase and Production}

Any business starts from its purchasing function, it is a prime function and purchase manager plays tactical role in getting right quality of goods in right quantity at the right place to avoid stock outs in the organization. Purchasing and production are the ongoing processes in any manufacturing industry. Managing ethical aspects has become one of the challenges in the business system and nowadays almost all companies have taken due care, because of its interaction with suppliers and external market. While carrying out purchasing responsibilities many factors should be taken into consideration like legal consequences of purchasing decision, purchasing in open and fair competition through legal sources with authentication. Transaction has to happen based on utmost goodfaith, avoiding compromising practices for unethical activities knowingly or unknowingly. Transaction should be built up in healthy relationship among suppliers and buyers to enhance future opportunities. Common unethical issues in purchasing are nepotism, accepting gifts by suppliers, illegal purchases, personal purchases, revealing confidential information to suppliers for money or providing misleading purchase information to the company etc.

Production operation is a function of converting raw-material into finished goods. It is nothing but using the resources and skills to outline a product as per the tastes and preferences of the customers. In this long process, so many ethical quality measures have to be taken to maintain the standards of the company. In fact it adds long term survival of the business in this competitive market. To keep consistency and to improve quality in the operations, huge fund is deployed to get qualitative work by using innovative and competitive technology like Total Quality Management (TQM), Six Sigma etc.

Production with quality is one of the dynamic factors in any organization. And it has to maintain quality in the product it produces till it reaches the hands of the customers. So maintaining quality measure ethically is one of the important factors. Production activities of a company should not cause 
damages to natural environment through its polluting elements and carbon emissions. They create natural disorders. So many companies like Skylark, Exxon, Shell, Union Carbide India Limited (UCIL) have made very deep damage for natural resources, in and around the world. Ethical measures relating to environment have to be considered by the companies to protect the nature and natural resources of the country.

Ethics should become an integral part of the business life. Unethical practice may generate a windfall gain. But it will not survive for a longer period. Ethics is dearl No Ethics is dearer!

\section{Ethical Dilemmas at Work Place}

Decision making is one of the important functions in any business. None of the work will start without scientific decisions in a corporate. So taking necessary decision among available alternatives is very important and it has to make sure that, it does not affect adversely anybody else within or outside the organization. Many a times corporate are exposed to "Ethical dilemma". In this kind of circumstances how well they resolve the problems is a challenging task and it indicates astuteness and capability of the manager. Before taking the decision, he/she has to scrutinize the things and identify the things to shun the problem. When a decision involves both negative and positive features, being a manager, he/she has to work out how negative feature has to be eliminated. Good example for this is introduction of computers in Banks. Few years ago it was a challenge for the banking sector. This was an ethical dilemma since it has its own advantages and disadvantages too. Advantages are many more, it saves time, accurate, less costly and customer friendly. It has disadvantages like when computers are introduced manual work force should be reduced since all mechanical work will be undertaken by the computer. Large numbers of employees are not required. This was a big ethical dilemma for banks in that point of time, because decision should be based on ethical grounds and should not harm anybody else. Then banking sector came to a conclusion with a favorable decision that, good compensation would be paid to those employees who would be replaced by the computers. It was an ethical decision. 


\section{Ethics in International Business}

Because of Liberalization, Privatization and Globalization (GLP) domestic companies started to do their business world wide. It is an opportunity for any company to create a good network with other countries and help in enhancing potentiality of the company. Many reasons are there why companies are going global to take advantage of cheap labor, cheap transaction etc. Many multinational companies can be seen in all over the world operating their business successfully through diversified strategy. When a business has a geographical spread, it creates a bench-mark to other companies to follow. But at the same time, the company cannot compromise its growth to ethics and social responsibilities. There are issues which are commonly raised in international business viz., bribing the authorities to get permission or to secure political influence to play role against competitors, not paying due respect for the law of the country or violating rules and regulation of the land, supporting unethical activities, not paying respect for human rights etc.

\section{International Marketing}

Advertisement is an effective channel to reach end users. So making efficient use of this in ethical way is very important to educate customers about the product. Sometimes it may be used in some other manner which will adversely affect system of the country. Common unethical practices in international marketing is demoralizing primordial cultures and customs without considering value of the country, false and fraudulent advertising in third world countries, manufacturing the product which is unsuitable to local needs, accepting the responsibility of producing perilous products which are unsafe for local requirement, promoting more and more marketing practices that squander precious resources of the deprived country etc.

\section{Technology and Economic Activities}

Technology is one of the strongest tools to meet expectations of the customer. Multinational companies of foreign origin start their business in developing countries by using the indigenous resources to the fullest extent except the advanced technology. Because, they presume that they are ahead of developing countries in utilizing the advancements in technology. This amounts to violation of ethical practices, as customers of companies in developing 
countries may not be able to appreciate, the level of technological sophistication in the products they use.

\section{Environment}

When MNCs are starting their operations in other nations, it is the responsibility of the company to protect these countries' environment with precautionary measures. Some of the MNCs give more importance for earning huge money through the business and create damage for the countries' environment viz., obliterate natural resources, polluting the environment, not paying or paying very less reparation for creating huge natural disorder etc.

\section{Conclusion}

Ethics is not only imperative in the corporate, even it is essential for everybody in their lives. Because it is a fundamental element and it is the base on which society is structured. In business, ethics is expected in each action, so executing the work ethically is very vital. By doing best for others, rather than ourselves ethics can be instilled. Business may loose something in the short run, but in the long run it will be at a profit. Hence, a corporate has to take necessary decisions on ethical grounds which are favorable to its employees, customers, Government, shareholders, media and the society. So that corporate can satisfy words of Mahatma Gandhi - GOOD ETHICS IS GOOD BUSINESS.

\section{End Notes}

1 News clippings watched on NDTV channel on Jan 08, (Thursday) 2009.

2 Compiled by the authors.

\section{Bibliography}

http://en.wikipedia.org/wiki/Business_ethics

hHtp://www.business-ethics.com/

http://www.enotes.com/business-finance-encyclopedia/ethics-marketing 